\title{
古典主義建築における視覚補正理論と空間スケール \\ THE THEORY OF OPTICAL ADJUSTMENT AND THE SPATIAL SCALE \\ IN THE CLASSICAL ARCHITECTURE
}

\author{
土居義岳* \\ Yoshitake DOI
}

\begin{abstract}
Vitruvius' theory of optical adjustment is based on the hypothesis that one sees the architectural order from a certain distance. This distance, which can be found out by a simple calculation, is about 60 feet and 120 feet. It is significant that these scales correspond to those of the inner space of the basilica that Vitruvius designed. In the academic discussions of the $17^{\text {th }}$ and $18^{\text {th }}$ century, his theory was sometimes approved and sometimes denied, but this ideal scale of space revived in its practical discussions.
\end{abstract}

Keywords: Vitruvuis, optical adjustment, academy, architectural order, scale ウィトルウィウス、視覚補正、アカデミー、建築オーダー、スケール

1 序

古典主義建築における視覚補正の理論はヴォルフガング・ヘルマン著 『クロード·ペロー』で詳しく述べられている1。しかし、視覚補正理論は、 理論的にはある一定の距離から見るということを前提として成立してい ると考えられるが、この点にはあまり触れられていない。

建物の部位で仰角が大きいものは、寸法を割り増しにするというのが 視覚補正理論の骨子である。ところで、かりに建物を2倍に拡大したと して、視距離も2倍にすれば、すべて同じ視角でみているから、補正の 必要はない。だから補正が必要であるからには、ある一定の距離から見 ているという前提がなければならない。

本稿では、ウィトルウィウスの建築書で展開されている視覚補正理論 が前提としているスケールを、計算によって割り出し、その理想的な視 距離が現実の都市や建築のスケールに対応していることを指摘する。ま た後世への影響の一例として、17-18 世紀にフランスの建築アカデミーに おいてなされた議論も分析する。

\section{2 ウィルクィウスの視鸴補正理詥}

\section{1 ウィトルゥウスの理詥の骨子}

ウイトルウィウスはその『建築十畫』(森田慶一訳)の数個所で視覚補 正について述べている（以下にたとえば[1.2.3]は建築書の第 1 書第 2 章 第 3 節、 $[4,5]$ は第 4 書第 5 章のこと)。一般的に、視覚はしばしば間違っ た認識をするから「場所の性状や実際の必要」に応じて比例を加減す るべきであり[6.2.1][6.2.4]、たとえば柱どうしの間隔が大きいほど空気
層によって「見掛けの上で食」われるので柱を太くし[3.3.11]、柱頭より

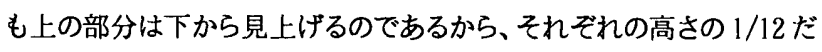
け前に傾けるべきである[3.5.13]。

こうした視覚の錯誤の原因は「映像の刺激あるいは自然学者が好ん でいう眼からの放射線の放出によって見ている」[6.3.3]から、すなわち 眼と対象物の両端がなす角度、すなわち「視角」が見かけのものの大 きさを支配しているからであった。

ところで2個所で具体的な数值をあげて比例を論じている。

ひとつは「柱の頂の頸部の縮まり」[3.3.12]すなわち上部直径と下部 直径の比であり、柱が高いはど、上部の直径はあまり縮められなくなる。 ウィトルウィウス自身「高さに差違があるので、眼の視線が昇るにしたが って太さに調節が加えられている」3.3.13]と述べている。

もうひとつはイオニア式オーダーにおけるアーキトレーヴ高さとコラム 高さの比である[3.5.8]。高い部分を見上げるとき視線は「感覚に不確 実なモドゥルス量を報告する」ので、建物が「それ自体が巨大である場 合には、大きな割付が行われるように肢体のシュムメトリアに常に割付け の補正が加えられるべきである」 [3.5.9]。すなわちコラムが高いほど、ア 一キトレーヴは相対的に大きな寸法が与えられている。

これら2個所で与えられた数值はじゅうぶんに詳細であり、オーダー の一般的な比例を前提とすれば、ある距離から見た場合に、各部分の 視角や、視角と視角の比を計算によって求め、視覚比のばらつきが最小 になるような視距離を逆算することもできる。 


\begin{tabular}{|c|c|c|c|c|c|}
\hline $\begin{array}{l}\text { コラム高さ } h_{c}(R) \\
\text { 值城の中央值 }\end{array}$ & $\begin{array}{c}(12) \sim 15^{(\otimes)} \\
13.5\end{array}$ & $\begin{array}{c}15 \sim 20 \\
17.5\end{array}$ & $\begin{array}{c}20 \sim 30 \\
22.5\end{array}$ & $\begin{array}{c}30 \sim 40 \\
35\end{array}$ & $\begin{array}{c}40 \sim 50 \\
45\end{array}$ \\
\hline $\begin{array}{l}\text { Vitruvius } \\
{[3.3 .12]}\end{array}$ & $\begin{array}{c}5 / 6 \\
(10 / 12)\end{array}$ & $\begin{array}{l}5.5 / 6.5 \\
(11 / 13)\end{array}$ & $\begin{array}{c}6 / 7 \\
(12 / 14)\end{array}$ & $\begin{array}{l}6.5 / 7.5 \\
(13 / 15)\end{array}$ & $\begin{array}{c}7 / 8 \\
(14 / 16)\end{array}$ \\
\hline $\begin{array}{c}\text { Alberti } \\
{[7.6]}\end{array}$ & $\begin{array}{c}5 / 6 \\
(10 / 12)\end{array}$ & $\begin{array}{l}11 / 13 \\
(11 / 13)\end{array}$ & $\begin{array}{c}6 / 7 \\
(12 / 14)\end{array}$ & $\begin{array}{c}13 / 15 \\
(13 / 15)\end{array}$ & $\begin{array}{c}7 / 8 \\
(14 / 16)\end{array}$ \\
\hline $\begin{array}{l}\text { Palladio } \\
\text { [1.13. 3] }\end{array}$ & $\begin{array}{l}5.5 / 6.5 \\
(11 / 13)\end{array}$ & $\begin{array}{c}6 / 7^{(\mathrm{b})} \\
(12 / 14)\end{array}$ & $\begin{array}{c}7 / 8 \\
(14 / 16)\end{array}$ & $\begin{array}{c}--^{(c)} \\
(15 / 17)\end{array}$ & $\begin{array}{c}-^{(c)} \\
(16 / 18)\end{array}$ \\
\hline
\end{tabular}

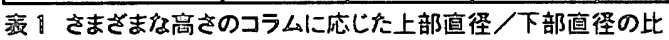

(a):下限はあたえられていないが、ーキトレ一高さ/コラム高さの比の場合は 12

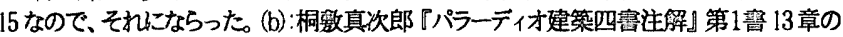
注3における、原文ては $6.5 / 7$ であるが $6 / 7$ が正しい、という指摘こ従った。(c):パラディオ

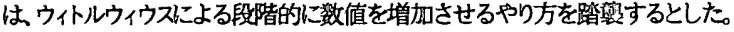

\begin{tabular}{|c|c|c|c|}
\hline 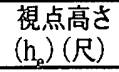 & $\begin{array}{l}\text { 視角比のばらつき } \\
\text { の敢小值 } \\
\end{array}$ & 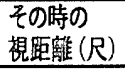 & $\begin{array}{l}\text { ぱらつき } 0.02 \text { 未満である視 } \\
\text { 距離の範曲 (尺) }\end{array}$ \\
\hline 5 & $0.014596 \cdots$ & 108.9 & $100.0 \sim 144.4$ \\
\hline 0 & $0.013378 \cdots$ & 119.8 & $107.5 \sim 163.3$ \\
\hline-10 & $0.01196 \cdots$ & 138.8 & $120.5 \sim 195.1$ \\
\hline
\end{tabular}

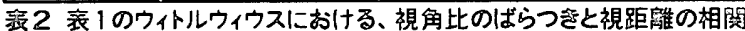

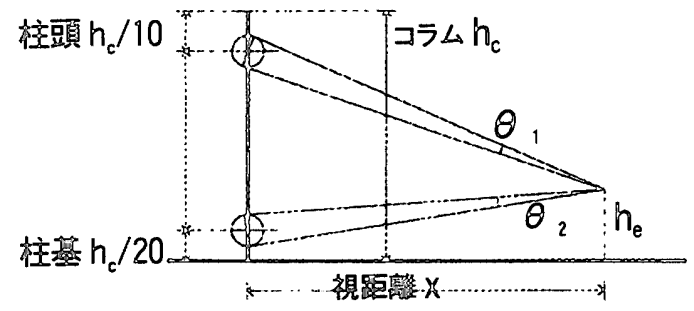

图 1 コラムの上部直径と下部直径の比の凡例
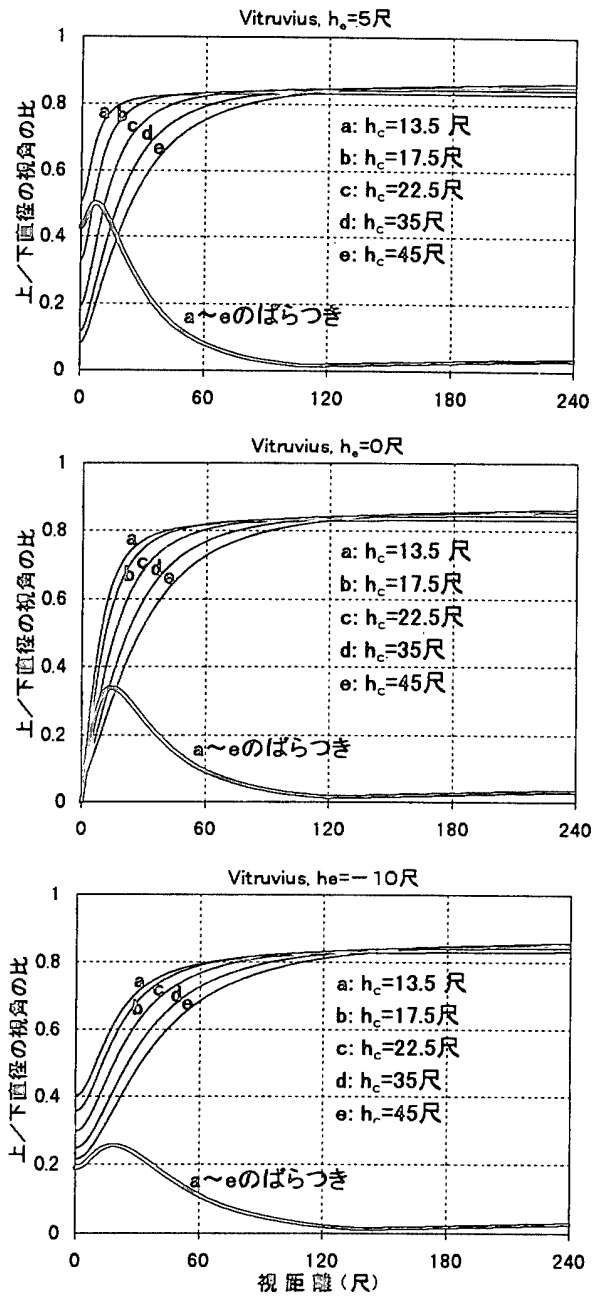

図3 コラムの上部/下部の面径の視角の比の分新

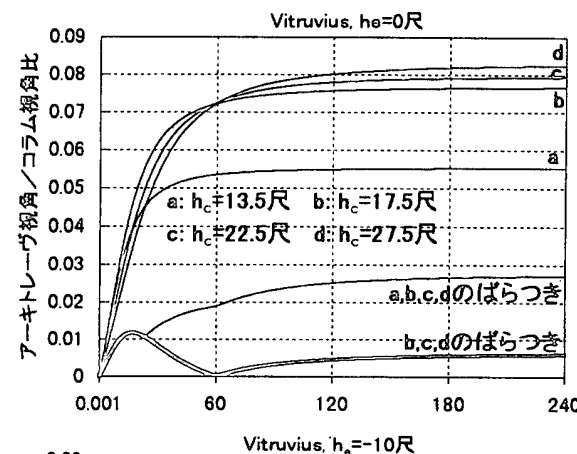

\begin{tabular}{|c|c|c|c|c|c|}
\hline \multirow[t]{2}{*}{$\begin{array}{c}\text { Vitrunius } \\
\text { [3.5.8] }\end{array}$} & 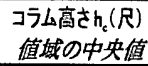 & $\begin{array}{c}12 \sim 15 \\
13.5\end{array}$ & $\begin{array}{c}15 \sim 20 \\
17.5\end{array}$ & $\begin{array}{c}20 \sim 25 \\
22.5\end{array}$ & $\begin{array}{c}25 \sim 30 \\
27.5\end{array}$ \\
\hline & $h_{d} / h_{c}$ & $1 / 18$ (a) & $1 / 13$ & $1 / 12.5$ & $1 / 12$ \\
\hline \multirow[t]{2}{*}{$\begin{array}{c}\text { Alberti } \\
{[7.9]}\end{array}$} & $\begin{array}{l}\text { Jラム高さ } h_{c}(R) \\
\text { 值城の中央值 }\end{array}$ & \multicolumn{2}{|c|}{$\begin{array}{c}\sim 20 \\
15\end{array}$} & $\begin{array}{c}20 \sim 25 \\
22.5\end{array}$ & $\begin{array}{c}25 \sim 30 \\
27.5\end{array}$ \\
\hline & $h_{\mathrm{e}} / h_{c}$ & \multicolumn{2}{|c|}{$1 / 13$} & $1 / 12$ & $1 / 11$ \\
\hline \multirow[t]{2}{*}{$\begin{array}{c}\text { Serlio } \\
{[4.7]}\end{array}$} & $\begin{array}{l}\text { Jラム高さ别(R) } \\
\text { 值城の中央值 }\end{array}$ & $\begin{array}{c}12 \sim 15 \\
13.5\end{array}$ & $\begin{array}{c}15 \sim 20 \\
17.5 \\
\end{array}$ & $\begin{array}{c}20 \sim 25 \\
22.5 \\
\end{array}$ & $\begin{array}{c}25 \sim 30 \\
27.5\end{array}$ \\
\hline & $h_{p} / h_{c}$ & $1 / 16^{(b)}$ & $1 / 13$ & $1 / 12$ & $1 / 11$ \\
\hline
\end{tabular}

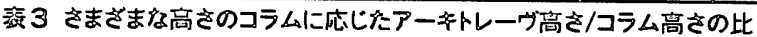

$h_{\mathrm{g}} / h_{\mathrm{c}}$ :アーキトレーヴ高さ/コラムの高さの比。(a):「柱の下部の太さの半分」と 規定されているが、直径はコラム高さの $1 / 9$ であるから[4.1.8]。(b) : 直径の半分て あり、直径はコラム高さの $1 / 8$ であるから[4.7]。

\begin{tabular}{|c|c|c|c|}
\hline $\begin{array}{l}\text { 視点高さ } \\
\left(\mathrm{h}_{\mathrm{o}}\right)(\text { 尺) }\end{array}$ & $\begin{array}{l}\text { 視角比のぼら } \\
\text { つきの最小值 }\end{array}$ & $\begin{array}{l}\text { その時の } \\
\text { 梘䠉踓 (尺) }\end{array}$ & $\begin{array}{l}\text { ぱらつきが0.001 以下を満た } \\
\text { す視距䧺の範团 (尺) }\end{array}$ \\
\hline 5 & $0.000258 \cdots$ & 56.4 & $51.6 \sim 62.4$ \\
\hline 0 & $0.000186 \cdots$ & 60.2 & $54.7 \sim 67.0$ \\
\hline-10 & $0.0000993 \cdots$ & 66.1 & $59.1 \sim 74.2$ \\
\hline
\end{tabular}

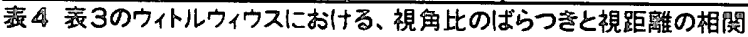

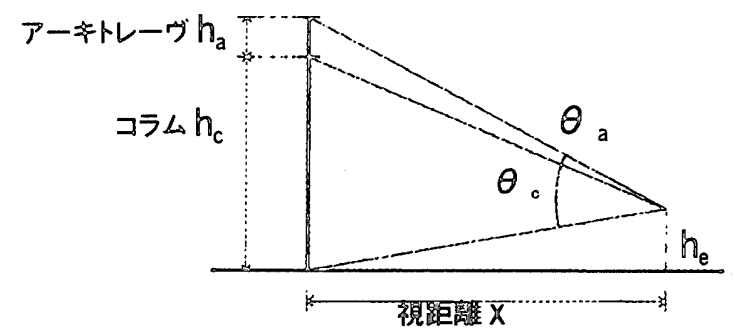

图2 アーキトレーウ高をとコラム高さの比の凡例
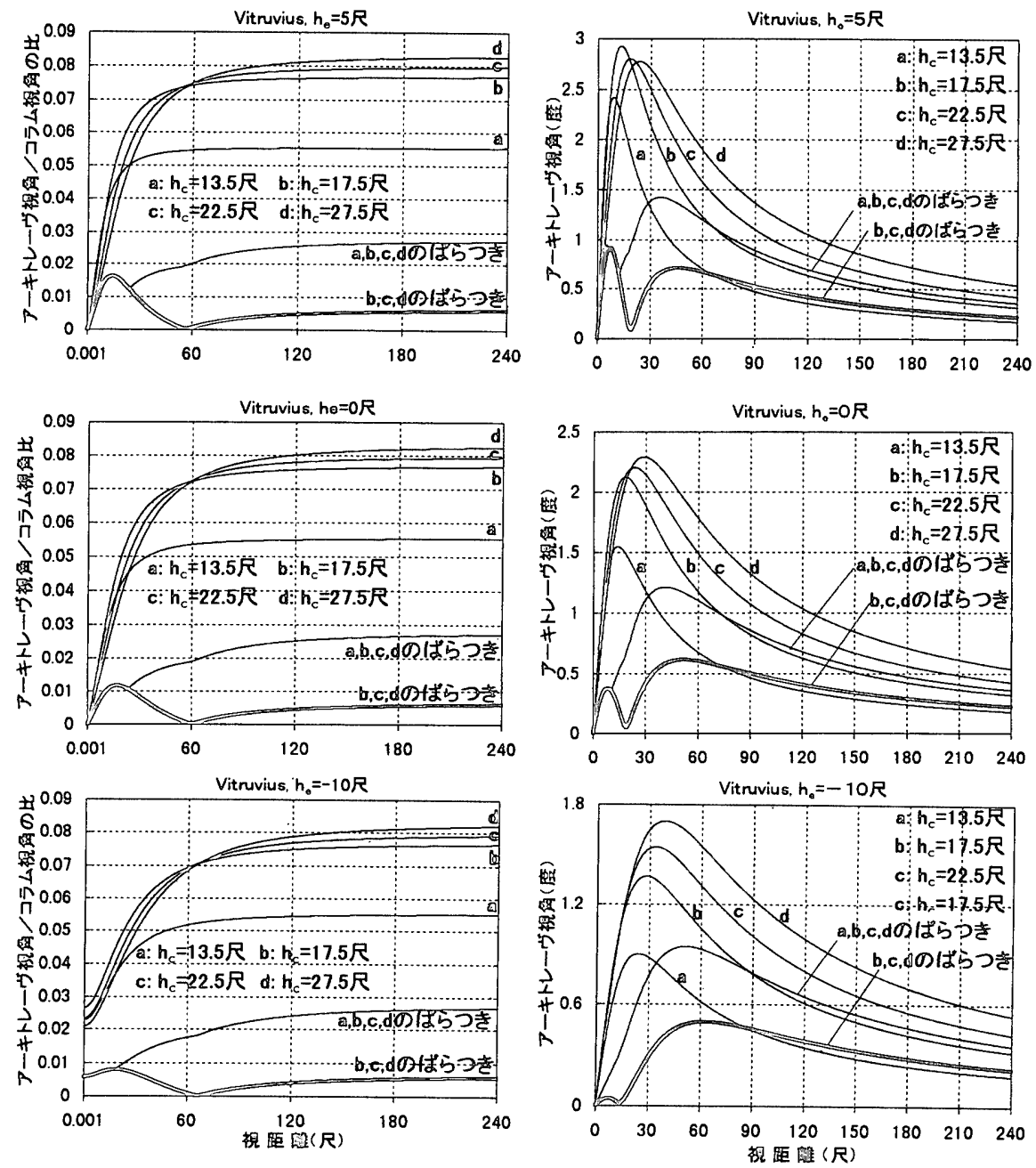

圆はアーキトレーウ离/コラム高さの視角の此の分新

图5 アーキトレーヴ視角の分析 


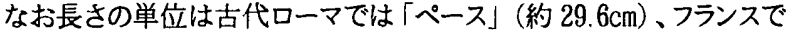
は「ピエ」(約 $32.4 \mathrm{~cm})$ だが、本稿では「尺」で統一する2。

\section{2 コラムの上部直㺯と下部直径の比}

\subsection{1 計算のための仮定（表 1)}

ウィトルウィウスがその建築書で与えた数値を表 1 のうう整理（その 理論を踏襲したアルベルティ、パラディオの比例も参考のためのに示す) したうえで、下記のように仮定する。

\section{(A) 視点の高さに関する仮定}

ウィトルウィウスは、神殿に関する記述のなかでスタイロベート[3.4.1-3] と基壇[3.4.5]に言及している。また古代においては柱基が直接床の上 にのる場合もある。本稿では、人間の足の裏から目までの距離を5年

(約 $150 \mathrm{~cm}$ ) と仮定し、コラムの最下端から視点までの高さ（下記のよう に $\mathrm{h}_{\mathrm{e}}$ とする)の 3 種類の場合を想定する。実際はさまざまな場合がある がこれらをめやすとして考えることができる。

(1) $h_{e}=5$ 尺。柱と人体がおなじ水平面上にたっている場合。

(2) $h_{\mathrm{e}}=0$ 尺。スタイロベートの高さが 5 尺で、コラム下端と眼球がおなじ 高さにある場合。

（3） $h_{\mathrm{e}}=-10$ 尺。高さ 15 尺の基壇のうえにある柱を、地面にたって眺める 場合。

\section{（B）オーダーの種類などに関する仮定}

直径の低減比はとくにどれかのオーダーではなく一般的な理論として 述べられている[3.3.12]が、共和制末期から帝政初期にかけて一般的に 公共建築で用いられたことの多いコリント式オーダーをここでは対象とし、 その一般的な直径／コラム高さの比 1/10を前提とする。

また簡略化のため、円柱ではあるが、厚みのないシルエットとして認識 されると仮定する。以下に「直径」とは正確には「幅」であるが、やはり 煩雑さをさけるためにそのままとする。

\subsection{2 視角の此の計算と、視医離（図 1，3、表2）}

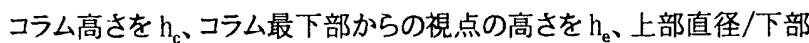
直径の比を $\alpha$ 、視距離を $\mathrm{x} 、$ とすると、上部直径の視角 $\theta$ ，と下部直径 の視角 $\theta_{2}$ の比は次の式であらわされる3。

$\frac{\theta_{1}}{\theta_{2}}=\frac{\operatorname{ATAN}\left\{\left(\alpha \mathrm{h}_{\mathrm{c}} / 20\right) / \sqrt{\mathrm{x}^{2}+\left(9 \mathrm{~h}_{\mathrm{c}} / 10-\mathrm{h}_{\mathrm{e}}\right)^{2}}\right\}}{\operatorname{ATAN}\left\{\left(\mathrm{h}_{\mathrm{c}} / 20\right) / \sqrt{\mathrm{x}^{2}+\left(\mathrm{h}_{\mathrm{c}} / 20-\mathrm{h}_{\mathrm{e}}\right)^{2}}\right\}}$

$\alpha 、 h_{\mathrm{r}} 、 \mathrm{~h}_{\mathrm{e}}$ はそれぞれの場合に与えられる定数なので、これは視距離 $\mathrm{x}$ の 関数である。本稿では $\mathrm{x}=0.1$ 尺から出発し、0.1 尺ごとに代入して、各高 さのコラムにおける視角比 $\theta_{1} / \theta_{2}$ 比、それぞれのコラム高さにおける視 角比のばらつき (最大値と最小值の差)を求めた。するとこれらは図3の ように描かれ、表2のように整理できる。

ここでは視角比のばらつきをより小さくする視距離が、理想的な視距 離であると考える。建築の視覚的な体験の諸条件はたいへん多様であ るので、理想的な視距離を目安としてラウンドナンバーで想定すると、た とえば120尺が考えられよう。また比較的ばらつきが小さい值域として 100〜180 尺が想定される4。またアルベルティ、パラディオの場合もほほ 同様の数值がえられた 5 。

\section{3 イオニア式オーダーのアーキトレーヴ高さ/コラム高さの比}

\subsection{1 計算のための仮定（表3）}

ウィトルウィウスは、アーキトレーヴとコラムの高さの比として比例を既 定しているので、両者の視角の比を指標とするのが妥当である、と仮定
する。彼が与えた数値を表3のように整理し(その理論を踏襲している アルベルティとセルリオが提案した数値も示す)、コラムと視点の高さ関 係に関しても2.2.1節(A)と同じ仮定をする。また值域 12〜15 尺におけ る比例は、他の値域のものと著しく異なっており、それは図4においても 視覚的に一目瞭然であり、これを別個のものと扱う。。

\subsection{2 視角の比の計算と、視距離 (図2、3、表4)}

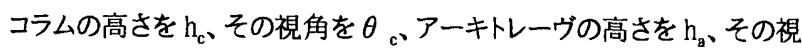
角を $\theta$ 、そして視距離をx、視点のコラム最下部からの高さを $\mathrm{h}_{\mathrm{e}}$ とすれ ば視角比は;

$$
\frac{\theta_{\mathrm{a}}}{\theta_{\mathrm{c}}}=\frac{\operatorname{ATAN}\left\{\left(\mathrm{h}_{\mathrm{a}}+\mathrm{h}_{\mathrm{c}}-\mathrm{h}_{\mathrm{e}}\right) / \mathrm{x}\right\}-\operatorname{ATAN}\left\{\left(\mathrm{h}_{\mathrm{c}}-\mathrm{h}_{\mathrm{e}}\right) / \mathrm{x}\right\}}{\operatorname{ATAN}\left\{\left(\mathrm{h}_{\mathrm{c}}-\mathrm{h}_{\mathrm{e}}\right) / \mathrm{x}\right\}+\operatorname{ATAN}\left(\mathrm{h}_{\mathrm{e}} / \mathrm{x}\right)}
$$

この場合もやはりこの $\theta_{\mathrm{a}} / \theta_{\mathrm{c}}$ はx $\mathrm{x}$ 関数である。これを前節と同様 に分析すると、それぞれのコラム高さにおける視角比のばらつきを最小 にする視距離としては、表4のように、目安として 60 尺というラウンドナ ンバーが考えられる?。

なおウィトルウィウスにおいてコラム高さ12〜15尺の值域を考慮すると、 他の3曲線と交わっているのはいずれも視距離 24 尺（約 7m) 以下の範 囲であり、これは室内のスケールである。またこの距離から高さ 20～30 尺の柱を見上げる場合、仰角は $45^{\circ}$ 以上と大きすぎる8

\subsection{3 イオニア式オーダーのアーキトレーヴの視角 (図5)}

前項は、アーキトレーヴの視角とコラムのそれの比が問題とされている という仮定に基づいているが、ウィトルウィウスのテキストを離れて実際の 状況を考えれば、コラム高さに比べて視距離が比較的小さい場合、ア一 キトレーヴの視角の絶対値 $\left(\theta_{\mathrm{a}}\right)$ を指標にすることも可能である。この場 合、図5に示されるように、コラム高さ12〜15 尺の值域はやはり除外す べきであり、また視角のばらつきが最小になるのは視距離 19.4 尺 $\left(\mathrm{h}_{\mathrm{e}}=5\right)$ 、 19.1 尺 $\left(h_{\mathrm{e}}=0\right) 、 14.2$ 尺 $\left(h_{\mathrm{e}}=-10\right)$ の地点である。ここでは 20 尺というスケ 一ルの空間を想定できる。

\section{4 仰角}

ウイトルウィウスは視距離にも仰角にも言及していない。しかしコラム 高さ50尺までが前提とされた場合は理想的な視距離の目安が 120 尺、 コラム高さ 30 尺までが考察された場合は 60 尺であるから、最大コラムを

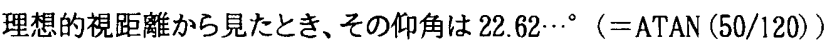
から $26.57 \cdots \circ$ (=ATAN (30/60) ) である。これらは上限であり、さらに 低い角度が一般的であったと考えられる。

3 クィトルィウスによるバシリカと古代都市におけるスケール

ウィトルウィウスは、自身が設計したバシリカの寸法を、列柱で囲まれ た広間が長さ 120 尺、幅 60 尺、円柱の高さは 50 尺、回廊の幅は 20 尺と 説明している[5.1.6]。これは視覚補正から導かれた理想的な視距離に ひじょうに類似する値である。

しかも 60 尺といったスケールは、へレニズムやローマの都市にしばしば 登場している。へレニズム都市にしばしば見られる列柱街路の幅員はま ちまちであるが、アゴラなどではストア列柱から記念碑の基壇までが 60 尺であることがしばしば見られ（図6）、古代ローマ都市におけるバシリ 力建築ではやはり主要広間の幅はしばしば 60 尺前後である(図7)。前 者はやはり視距離が意裁された結果だと考えられる。後者は、木造大卜 ラス構造の小屋組みの標準スパンということも考えられる。しかし 60 尺 というスケールがさまさまな局面で登場するとき、それがある種の標準 


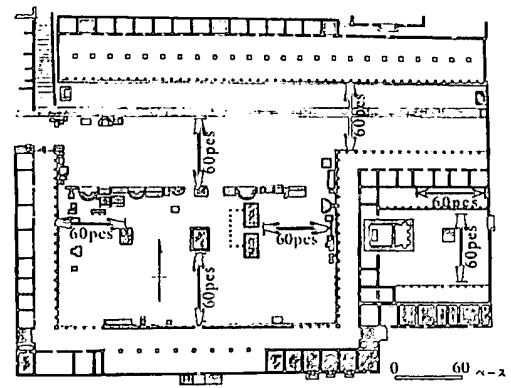

圆6 プリエネのアゴラ周辺（笑印は60ペース（尺）のスケール亦示す）

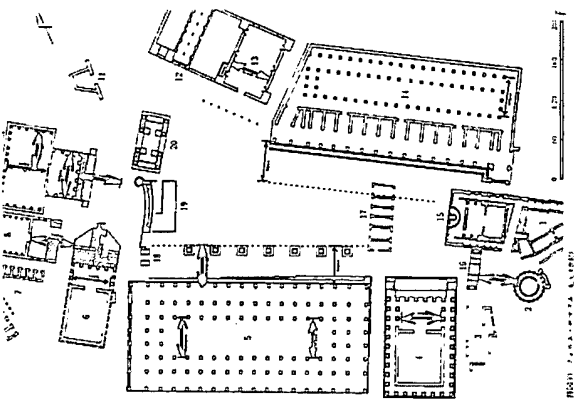

圈7ローマのフォルム・ロマヌム（矢印は60ペース（尺）のスケール示す）

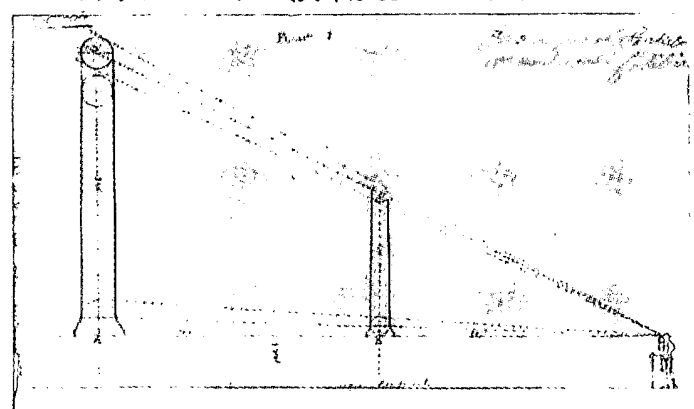

图8 Pierre Bullet, I.F., Papiers Beausires[B9.4e.31]の活图

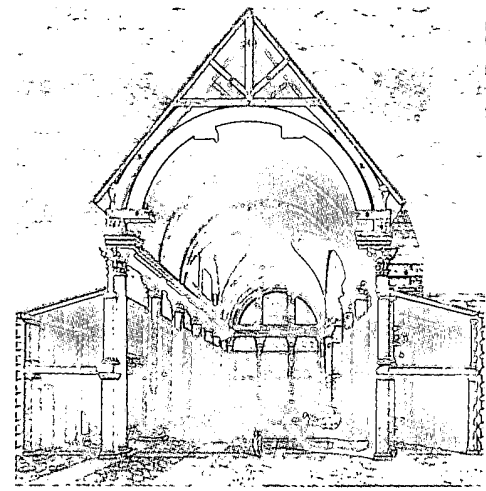

圈9 Cl. Perrault, Les Dix Livres d'Architecture de Vitruve, 1684, pl.XL （ペローが復元したウィトルウィワス設的のバシリ方）

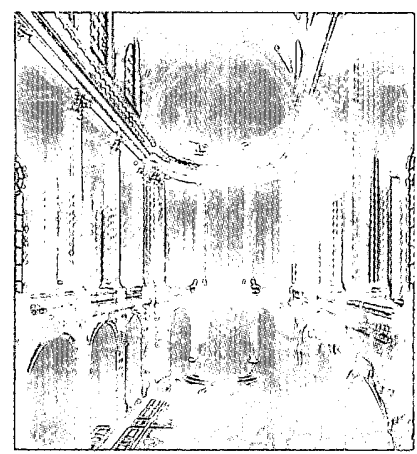

図 10 ベルサイユ葛チャペル

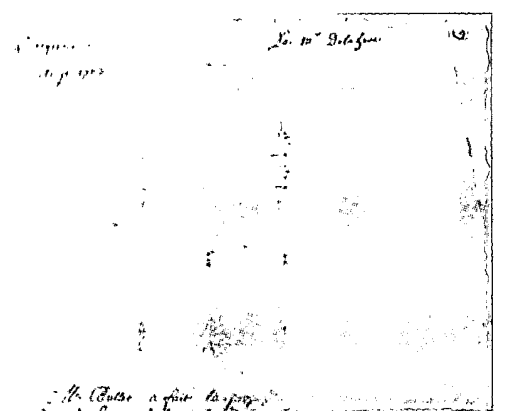

图 11 La Hire, I.F., Papiers Beausires[B9.4 e.671

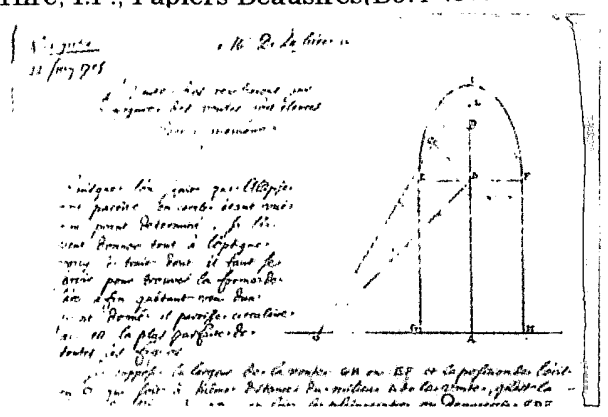

图 12 La Hire, I.F., Papiers Beausires[B9.4 e.28]

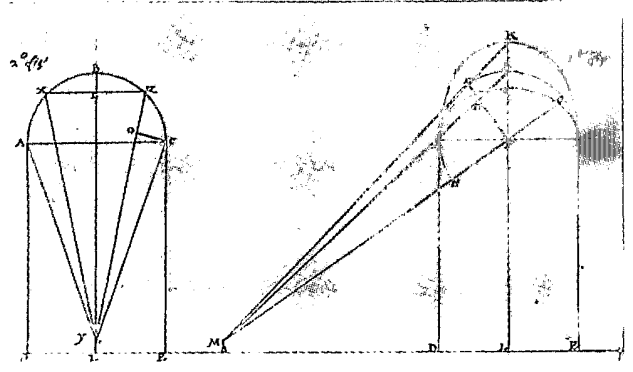

图 13 Bullet, I.F., Papiers Beausires[B9.4 e.29]

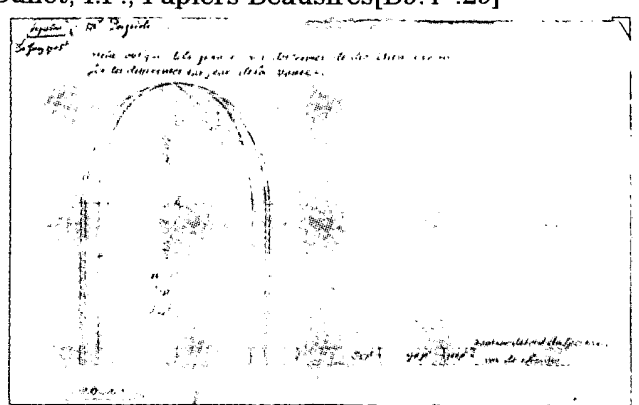

图 14 Desgodetz, I.F., Papiers Beausires[B9.4 e.30]

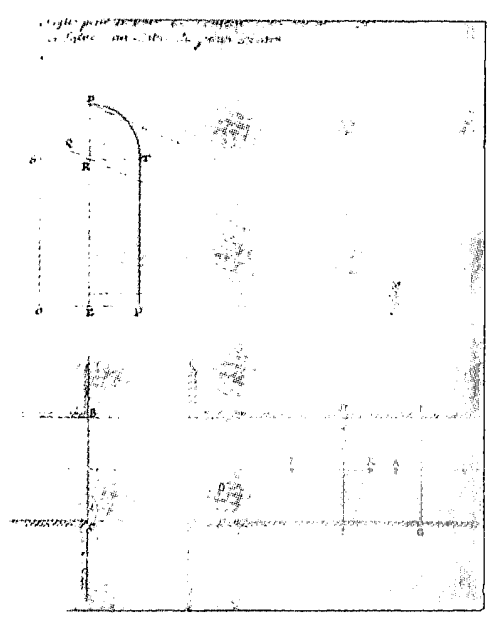

图 15 Desgodetz, I.F., Papiers Beausires[B9.4 e.30] 
スケールのようなものであったと想定するしかない。

こうした 60 尺などのスケールが前提とされたと仮定しないとウィトルウ イウスの理論が成立しないことはすでに指摘した。一方こうしたスケー ルは、彼が登場する以前のへレニズム時代にすでにしばしば都市空間の なかに発見される。このことから判断して、彼の理論が現実の都市空間 に適用されたというより、まず現実の都市や建築の空間がそもそもこう したスケールによって構築されていたので、ウィトルウィウスは無意識的に それを前提として自己の視覚補正理論を提出したと考えるのが妥当で ある。

\section{4 フランスの建筮アカデミーにおける視営補正理論の受容}

こうしたウィトルウィウスの視覚補正理論を 17〜18 世紀の建築アカデ ミーは受容した。この受容過程はふたつのレベルに分けて考えなければ ならない。すなわちウィトルウィウスやその後継者たちがテキストのなかで 明快に展開している理論そのものと、前述で指摘したような、テキスト中 では明言していないが、しかし一定のスケールを前提としているという 点である。

前者の言明された理論に対して、初代教授フワンソワ・ブロンデルは肯 定的であり、クロード・ペローは否定的であった9。3代目教授デゴ゙は、 古代ローマ建築においてはコラムの寸法と、上部直径/下部直径の比は 相関性が見られないことを数字をあげて示し、アカデミーも直径の低減 はコラム高さではなくオーダーの種類によると指摘した10。またアカデミー は、コラムが2倍の高さになっても、視距離を2倍にすれば比例を割り増 しにする必要はないと論じている"1 (図8)。

すなわち後者の、一定の視距離が前提となるという言明されざる点 は、アカデミーやその建築家たちはあきらかに理解していなかった。

\section{5 建杽アカデミーにおける教会堂内部空間に関する議覦}

\section{1 ヴェルサイユ宮礼拝堂}

1689 年にアカデミーは当時計画され建設されたヴェルサイユ宮のチャ ペルについて議論している。J.-H.マンサールはこのチャペルの設計図を 持参した12。ロビン・ミドルトンによれば、クロード・ペローが、この礼拝堂の 建設に関わっていた13。実際その内部は、ペローによるとされるルーヴル 宮東ファサードとの類似性が指摘されている14。またペローは、ウィトルウ ィウスが設計したバシリカを復元している(図9)が、それはヴェルサイユ 宮チャペル15（図 10）によく似ている。また自分自身が設計した天文台 の大広間のヴォールト天井の幅は「ウィトルウィウスのバシリカよりもわず かに小さいにすぎない16」とも述べている。こうした点から、この礼拝堂 に関して前述のバシリカが参考にされた可能性が大きい。

\section{2 教会堂のヴォールト天井の断面形状に関する議論}

この主題は 1703 年と 1705 年に集中的に議論された。ヴェルサイユ宮 礼拝堂建設に触発されたものであると同時に、この議論で前提とされ た内部空間のスケールは、ウィトルウィウスの視覚補正理論において暗に 示されていたそれに符合する。

\section{2 .11703 年9月3日の会合}

1703 年 9 月 3 日の会合で、ピエール・ビュレ17は教会身廊において使 われるべき大オーダーの高さを議論することを提案、アカデミーは、身廊 幅に対するヴォールト天井の高さを議論することを決定した上で、規模 が変化すれば比例も変化するからまず幅を 10 トワーズ (1トワーズ toise $=6$ 笑) すなわち 60 尺、と仮定した上で審議を進めることに決定した ${ }^{18}$ 。 この会合において作成されたフィリップ・ド・ラ・イールの文書は「教会の 身廊の高さは幅に比してどのくらいであるべきかというビュレ氏の提
案」に答えるものであり、身廊の幅10トワーズが想定されていた（図11） が、とはいえ内容そのものはヴォールト曲面が下から正確に見えるかど うかに関するものであった19。アカデミーは別の会合で、ローマのサンピエ ト口大聖堂の身廊幅 13 トワーズは広すぎると述べている20ので、10トワー ズはたんなるラウンドナンバーではなく、好ましいスケールと認識されてい たと思われる。

すなわち、ぺローにおいてもアカデミーの議論においても、ウィトルウィ ウスがその建築空間に与えた 60 尺というスケールが踏襲された。しかし それが視覚補正理論と連動するものとして理解されたことを示す資料 はない。ウィトルウィウス自身がその関連に無自覚であったのだから、ア カデミーもおそらくそうであったと思われるし、両者の関連を認識してい たことを示す資料はない。

\section{2 .21705 年6月 15 日の会合}

ラ・イールはこの会合でレポートを提出し、見かけは半円であるが実際 は棈円であるようなヴォールト断面を提案した ${ }^{21}$ このレポートはもっぱら ヴォールトの形状に関するもので、図版は添付されていなく、またスケー ルに関する言及は少ない。ただアカデミーは、このラ・イールの議論は有 用であり「光学 (視覚矯正) 理論に従って suivant les regles d'optique」 考察すべきであり、ディオクレティアヌス帝の浴場の建築家は同様なこと を考えたので、ヴォールトの高さを幅よりも大きくしたようである、と指摘 した22。なおアカデミーがしばしば準拠しデゴデによる実測図面集『ロー マの古代建築 Les Edifices Antiques de Rome』(Paris, 1682)によればここ の浴場の中央ホールは、幅が、壁の内法で約 74.3 尺、コラムの内法で 62.3 尺、長さは約 183 尺であり、やはり60尺とその3倍の180尺というス ケールを含んでいた。

\subsubsection{5 年6月 22 日の会合 (半円錐の断面としての半楕円)}

ビュレとラ・イールは、やはり教会堂の幅 10トワーズの身廊空間を想定 しながら、楕円断面のヴォールト天井を提案した23。彼らは眼球をその頂 点とする半円錐の断面としての半楕円を提案した。

ラ・イールは、実際の形が棈円形であれば見かけの形状は「あらゆる 形のなかで最も完全な円」となると前置きしたうえで、視点の位置は地 面からヴォールトが始まる地点までの高さと等しい距離だけ壁から離れ るべきだとして、視距離 15 トワーズ (90 尺) を(図 12)想定した24。

ビュレは、ラ・イールの主張に同意しながら、棈円ヴォールトは古代でも ディオクレティアヌス帝の浴場において使われているので是認されるべき だと述べた後、視点の位置に関しては、自然な視線の角度は「半直角 すなわち 45 度」であるから「妻壁から20トワーズ離れた」地点が理想的 な視点であるとした上で、罒に示されたような作図法に従ってアーチの 高さと曲線を求めた 25 (図 13)。ここで視距離 20 トワーズはすなわち 120 尺である。

\subsubsection{5 年6月 30 日の会合 (半円柱の断面としての半楕円)}

この日の会合でラ・イールとデゴデがレポートを読み上げた ${ }^{26}$ 。ラ・イー ルは、ディオクレティアヌス帝の浴場の大ヴォールトはアントワーヌ・デゴデ の実測結果から判断すれば棈円ではないと指摘27。一方デゴデは、この 浴場の大ヴォールトを視距離 $60 、 90 、 115$ 尺から見た場合を検討 (図 14）した上で、ラ・イールやビュレがいわば仮想の円錐を設定したのに対 して仮想の円筒を使い「真っ直ぐな円筒型の斜めの断面」から得られる 棈円のカーブを求めたが、視点の位置をヴォールト高さの 1.5 倍、すなわ ち 30 トワーズ (180 尺) の距離にある点とした28 (図 15)。

こうした議論のなかにウィトルウィウスの120１80尺という理想的視距 
離が復活している。もっともこの視距離は、ウィイルウィウスの場合はオー ターの見かけの比例から、アカデーの場合はウォールトの断面形状から 由来しているという相違はある。しかし 60 尺という基本寸法から出発 したことが決定的であるのは明らかである。

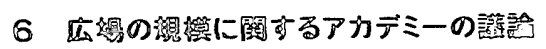

1674 年 1 月 8 日の会合では、パラデイオの『建築四書』[3.16]が講読 され、広場周囲の建物の高さ（以下「高さ」）は広場の幅 (以下「幅」) の1/6以下でも、1/3以上でも不適当というパラディオの記述に、会員の 意見はさまざまであった 29 。翌1月15日の会合では、「高さ」は建物の 用途によってさまざまであり、広場の規模もまちまちであるから、それら の比例怔一義的な值はないとした ${ }^{30}$ 。

フランソワ・ブロンデルはその『建築教程』[5.4.6]で、セルリオ、アブラ アム・ボス、デザルグらに依越しながら見かけの大きさは視角によってき まるという視覚補正理論を紹介したのち、建物全体を見るときは高さの 2倍の距離から、細部を見るときは建物高さと同じ距離から見るべきで あるとも指摘した 31 。

ところが 1689 年 12 月 2 日の会合では「高さ」は「幅」の $1 / 6$ である べきという記述があり32、翌 9 日の会合では、その比は $1 / 5$ から $1 / 6$ が適

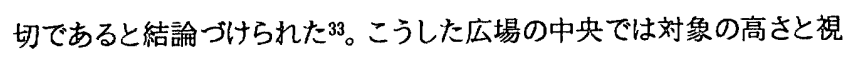
距離の比は $1 / 2$ から 1/2.5 であり、ウイトルウィウスの理論と一致する。

さらに 1703 年 5 月の 1 日、14 日、21 日の会合 34 では、建物の全高を 把暒するためには視角は「22.5占以下でなけれはなならないとされた。 た例として建物高さ 10 トワーズ (60 尺)、建物と視点の距離 25 トワーズ (150 尺) が想定された。この時、仰角は ATAN(10/25)=21.8014_..であ り、22.5以下である。こうした值は前述のウィトルウィウスの理論の筇囲 内である。実際、当時建設されだ゙ィクトワール広場は半径 20 トワーズ (120尺)、ヴァンドーム広場の計画図では台座の手前から向いのファサー ドまでの距蜼は27トワース (162 尺) ほどである。したがってアカデミーの 議論は、現実の広場を念頭に置いたものと想像される。

7 絔諭

視覚補正理諭はある空間的スケールを前提としていることは理論的 にいえる。どの高さのコラムであれ比例が一定に見えるような理想的な 視距離は、計算によれば 60 尺、あるいは 120 180 尺等である。

こうしたスケールは明確には認識されないまましかし準草された。

アカデミーはたしかに、古代ローマ建筑の実測調㚗から判断して、視 覚補正が使われた可能性は低いと判断したが、それはオーダーの各部 の比例に関してであった。反対に、視覚補正理諭が前提としているスケ 一ルには、いわは無自覚のままであったが、忠実であった。

視覚補正理論は、建筑や都市の空間的スケールをきわめて能弁に反 映していた。ウィトルウィウスが設計したバシリカ、古代のアゴラやフォル ム、建築アカデミーが㨾論したヴォールト空間や広場、におけるスケール は視覚補正理論から演繹される效值を満たすものであった。

以上から結論として次の2 点が指摘される。

(1) 視覚補正理論は、建築に「適用」されたというより、現実に存在す る建築や都市のスケールを前提としてそれを「反映」している。

ウィトルウィウスの場合は、広場に置かれた記念碑と列柱の距離、バシ リカの主要空問の幅など、公共空間にしばしば見られる寸法であった。 彼はそうした空間的現実のなかで生きていたからこそ、経験的にあるい は無意諳的にこのスケールを前提として、視覚補正を考えた。彼は60尺 というスケールを満たすバシリカを設計したが、この建築が、アカデミー
の教会建築に関する議論の出発点となった。ただし視覚補正理論があ る一定の視距離を前提としているという点は明確には意裁されなかっ た。そして逆説的だが、無頓着でありつつ、現実にはその 60 尺というス ケールを多用している。これもまた「反映」の一例である。

（2）この理論は、見られる対象となる建築の部位や細部より、むしろ視 点の位置、視距離に関わっており、この点で空間のスケールと関係が梁 い。

視覚補正理論は、むしろ即場の舞台装置の設計やさまさまな暊し絵 など、本稿で論じたウィトルウィウス的な伝統以外の場所で、重要なもの として論じられてきた分野である。しかしウイルルウィウスとその後絰者の 例に関する分析が示すのは、やはり視覚の根底には、視点と対象の空間 的関係があり、その最も本質的な倒面が「スケール」である、という事 実である。古典主義の建築は、ある側面では、こうした視覚における視 点と対象の空間的関係を調節する理諭であり装㯰でもある。建筑は視 覚的に調節されたり、その視覚的な関係性の対象となるだけではない。 建築はまさに、この視覚的な関係性を指示しあるいは積爾的に包み込 むものである。こうした観点からは、むしろ視覚そのものが、そもそも空 間的にして建筑的に構築されているともいえる。

なお本研究は文部省科学研究惯 (基盤研究(c)(2)、課題番号 08650750、代表 土居筑岳)によるもので、把論『ウイトルウィウスの視覚補正理諭の論理的尖結と しての理想的視覚距離』(日本建築学会中国・九州支部研究報告、第 10 号、 1996 年 3 月) および『ヴォールトの断面形状の視覚補正に関してフランスの王立 アカデミーでなされた謑論』(同)を加等し整理したものである。

注:

凡例

P.V. = Procès-Verbaux de l'Académie Royale d'Architecture 1671-1793, éd. Henry Lemmonier, 1911-29 (アンリ・ルモニエ編『王立建筑アカテミー (1671-1793)誥事録』)

I.F. = Institut de France (フランス学士院)

1 Wolfgang Herrmann, The Theory of Claude Perrault, London, 1973, pp.70-94.

2 ウィトルウィウスの建築售を勫訳したクロード・ペローらは、尺をそのままピエに 当てはめている。

3 下部直径 $=h_{c} / 10 、$ しがって下部半径 $=h_{c} / 20$

上部直径 $=\alpha h_{\mathrm{c}} / 10 、$ したがって上部半径 $=\alpha \mathrm{h}_{\mathrm{c}} / 20$

柱頭高さ $=h_{c} / 10$ 、柱基高さ $=h_{c} / 20$

眼球から上部直径まで視缐の長さ $=\sqrt{\mathrm{X}^{2}+\left(9 \mathrm{~h}_{\mathrm{c}} / 10-\mathrm{h}_{\theta}\right)^{2}}$

Фえに $\theta \quad{ }_{1} / 2=\operatorname{atan}\left\{\left(\alpha \mathrm{h}_{\mathrm{c}} / 20\right) /\left(\sqrt{\mathrm{X}^{2}+\left(9 \mathrm{~h}_{\mathrm{c}} / 10-\mathrm{h}_{\mathrm{e}}\right)^{2}}\right)\right\}$

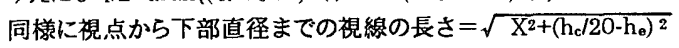

$\theta_{2} / 2=\operatorname{atan}\left\{\left(h_{c} / 20\right) /\left(\sqrt{X^{2}+\left(h_{c} / 20-h_{\mathrm{e}}\right)^{2}}\right\}\right.$

4 過度に巣密さをもとめても視覚そのものがその戦密さには耐えられない。たと えば1\%の寸法の違いは、すく間近に並べてみるのでなければわからない。

5 アルベルティの場合は、ウイトルウィウスとまったく同じ。パラデイの場合、 $h_{\bullet}=5,0,-10$ においてそれぞれ108.3尺、119.2尺、137.8尺が視角比のばらつ きが最小となる視距離。

6 この值域における規定は、ある種の例外規定、たとえば住宅や宮段の室内と いった特然条件を念頭においていると考えられる。アルベルティもそれゆえ 20 尺以下を1值域にまとめたとも推測できる。

7 アルベルティにおいては、 $\mathrm{h}_{\mathrm{e}}=5 、 0 、-10$ の場合において、視角比のばらつきを最 小とする視距離は 40.8、43.1、45.6 尺であり、セルリオの場合はそれぞれ 36.7、 38.0.38.2 尺であった。ルネサンスにおいては古代よりも小さな空間が前提とな 
っていたことをうかがわせる。

8 すなわちこの場合、柱全体を一挙に視野のなかに収めることはできない。だか らアーキトレーヴ視角の絶対值を指標とし、20〜30の高いコラムを室外で見て、 その記憶を保存したまま視距離の異なる室内で 12 15 尺の柱を見る場合に のみ、ウィトルウィウスの視覚補正理論は実際的な意味がある。

9 Wolfgang Herrmann, op.cit., pp.31-94, 130-145

101699 年 10 月 5 日の会合。P.V., t.III, pp.78-79. ただしアカデミーはそれで も建築家は視覚補正によって同じ比例に見えるようにするべきとした。デテテ が提出したレポートは I.F., Papiers Beausires[B9-3e-14]。

111706 年 11 月 15 日の会合。P.V., t.III, pp.257-258. ヒュレのレポート (I.F., Papiers Beausires[B9-4e-31])にもとづいて鸼論された。このレポート中でヒ ユレは、コラムが2倍の高さになっても、視距離を2倍にすれば比例を割り增しに する必要はないと論じている。

121689 年1月 28 日の会合。P.V., t.II, p.174. アカデミーは「高さは幅の2倍よ りも 4 尺高い」と指摘。この提出図面も現存しておらず、1699 年着工の現在 の礼拝堂とは無関係である。しかしヴォールトと天井の場合、高さは幅の2倍と いうのが基準となることをアカテミーが証識していたことは確かである。

13 Robin Middelton and David Watkin, Neoclassical and 19th Century Architecture/1, Milano, 1980, p.14. またぺローは、サント・ジュヌヴィエーヴ 教会計画 (1680 年頃) や、ジャン・マロ作画のバールベック神殿復元図 (1680 年頃)らをとおして教会堂のデザインをスタディしていた。

14 Jean-Marie Pérouse de Monclos, Histoire de l'Architecture Française-De la Renaissance à la Révolution, Paris, 1989, p.292

15 もっとも寸法は異なっている。このチャペルの寸法は、J.Fr.プロンテルの『フ ランス建筑』によれば、側廊をふくめて内法で長さ 22 トワース 1 尺（133 尺）、 幅 11 トワーズ 4 尺 (70p)、天井高さ 13 トワーズである。またビガニオールによ れば身郎幅 31 尺 $5 / 12$ 。ref. P.V., t.II, p.174

16 Claude Perrault, Les Dix Livres d'Architecture de Vitruve corrigés et traduits nouvellement en en Français, avec des Notes et des Figures,

Paris, 1684, réédition, Bruxelles, 1979, p.152, note.10. ペローはこの訳注 でさらに、バシリカ中央部分はほかの巽本にあるような平らな木造天上ではなく、 円筒形のヴォールト天上であったはずだとして訂正している。

17 Pierre Bullet, 1639-1716 建築アカデミ一会員

18 P.V., t.III, p.182

19 I.F., Papier Beausires [B9-4-67] 1703 年 9 月 3 日付。この文書中の図版 (図 11) では、アーチの要石までの身廊高さが 20 トワース、身鿾幅が 10 トワー ズ、オーダーはコリント式で高さ10トワーズであり、エンタブラチュア上に高さ1ト ワース $3 / 4$ の垂直の台石(piedroit)がのり、さらにその上に半径 5トワーズの半 円ウォールトがのるとされていた。その理由は「なぜならこうしないとアーチは つぶれてたように見えるだろうから」である。しかし「‥曲線と直線が出会う 屈曲点(jarret)が現れざをえない。こうした訳でエンタブラチュアから上に 3/4トワーズいった点でアーチを開始し、円弧全体を半棈円で形作ることが適 切であると考えられる。なぜならこの部分はコーニスの張出しによって隠されて

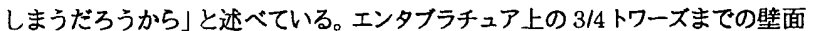
はコーニスによってほほ暚されるから、屈曲点がみえなくなるというその主張の 正当性も裹付けられる。

201710 年 2 月 10 日の会合。P.V., t.II, p.151

21 I.F., Papiers Beausires [B9-4-28A] 1703 年 6 月 15 日付。半円ヴォールト を下から見上げるとつぶれたように見えるので、通常は半円ア一チの下に「台 石 piedroit」をかましてアーチの出発点をエンタフララチュアの上端からすこし 離すことがなされるが、この方法では「アーチの上の部分がひしゃげて見えると いう重大な欠宿」を镉正できない、と指摘。つついて彼は、断面が半円ではな く半棈円のウォールトを使用すれば見かけ上は半队に見えること、この半楕円 ア一千は構造的には有利であること、しかし台石の形状がすべて異なってくる ので石工の仕事を著しく増やすというう不利もあることを指摘している。また 彼は半径の異なる円弧を慗げる簡便な楕円作図法は「屈曲点 jarret」(すな わち曲率の異なる曲線が出会う点）を生むことになり「少しばかり緎細な目」 の持ち主でもそれに気づいて不快な思いをすると述べている。

22 P.V., t.III, p.220

23 P.V., t.III, pp.220-221 ビュレは『身廊ヴォールトの高さを半円よりも高くす るというラ・イール氏の提案に関する考察』と題されたレポートを提出した。

24 I.F., Papiers Bequsires [B9.4e.28B]（1705年6月 22 日付）困 12 にお いて点Aから15トワーズ (90尺) 離れた点が視点である。詳細に関しては抴論
『ヴォルトの断面形状の視覚補正に関してフランスの王立アカテミーでなされ た議諭』日本建築学会中国·九州支部研究報告、第 10 号、1996 年 3 月、717 $\sim 720$ 頁参照。

25 I.F., Papiers Beausires [B9.4e.29] 1705 年6月 22 日付。ヒュレはこの文 書の中で、半円アーチよりもどのくらい高さを大きくするか、具体的にどのう.よ うなカーブを与えるか、という2点に問題を定式化した。彼はアカデミーの指摘 にしたがって幅 10 トワーズ、高さ 20 トワーズの身廊に即して考えた。作図として は、まず視点 $\mathrm{M}$ と点 $\mathrm{F}$ を結ひ、、点 $\mathrm{G}$ まで延長し、その線分上に半円 NIGを描 き、MI の延長線と LB の延長線の交点を $\mathrm{K}$ とすれば、FK が求める楕円の大 きい半径である。曲線の作図法に閔しては、しかし、図版の痕跡等から、大小 の円弧を組み合わして棈円としている。特徴的なのは「線分 MFを軸とし観察 者の目があると想定される点を頂点とする半円錐」を前提とし、この半円錐の 断面 NIG が見かけのアーチの形状で、これは半円形であり、これが壁面に投 影されると半棈円 NKGとなるが、これが実際のアーチの形状である、とした点 である。古代以来「光学 optique」では視覚の三角形を想定することが一般 的であるから、これはそれを立体的な問題に忍用したこのであると考えられ る。

26 P.V., t.III, p.221

27 I.F., Papiers Beausires [B9.4e.28C] 1705 年6月 30 日付。浴場のヴォール トの形状は、「デコデ氏が持ち龽った正確な実測に従って」すなわちデコテの 『ローマの古代建築』の図版を資料として検討されている。前掲拙論参照。

28 I.F., Papiers Beausires [B9.4e. 30] 1705 年 6 月 30 日。この文書のなかで 彼は「この手法によればヴォールトは、光学の法則にしたがって円錐から得られ る桂円の場合よりも、見る者にはより背が低くもっと円らしく見えるのであり、な ぜなら見る者は判断によって目に映るままの姿とは違った風に認識するからで ある」と指摘している。したがって補正の幅は小さく、ラ・イールが 1703 年 9 月 3 日に提出したと思われるウォールト断面図に近いものとなっている。

29 P.V., t.I, p.56

30 P.V., t.I, p.57

31 François Blondel, Cours d'Architecture, 1683, 5ème Partie, Livre IV, Chap.VI.

32 P.V., t.II, p.187

33 P.V., t.II, p.187

34 P.V., t.III, p.174-175

（1999年 2 月 10 日原稿受理，1999年 4 月 23 日採用決定 